\title{
KINERJA BIAYA PROYEK PEMBANGUNAN GEDUNG KANTOR SEMENTARA BUPATI TORAJA UTARA
}

\author{
${ }^{1}$ Parea Rusan Rangan, Staf Pengajar Program Studi Teknik Sipil, UKI Toraja \\ Email :usd blessing@yahoo.com \\ ${ }^{2}$ Nelson Numpu, Program Studi Teknik Sipil UKI Toraja
}

\begin{abstract}
ABSTRAK
Pembangunan di bidangjasakonstruksimasihterusdilakukanuntukmemenuhifasilitas fasilitasperkantoran yang memadai. Penelitian ini bertujuan untuk meninjau Kinerja Biaya Proyek khususnya pada Proyek Pembangunan Gedung Kantor Sementara BupatiToraja Utara di Kabupaten Toraja Utara.

Kinerja biaya proyek dianalisa berdasarkan indeks performansi biaya dan waktu, akan tetapi dalam penelitian ini dibatasi hanya pada performansi biaya. Perhitungan dianalisa dengan menggunakan Metode "Konsep Nilai Hasil ". Metode ini memberikan gambaran tentang informasi status Kinerja Proyek pada suatu periode pelaporan dan memberikan informasi prediksi biaya yang dibutuhkan untuk menyelesaikan seluruh pekerjaan berdasarkan indikator kinerja saat pelaporan yaitu indikator Cost Varian bernilai positif berarti biaya pekerjaan lebih kecil dari anggaran dan Indek Kinerja Biaya lebih besar dari 1 ( $\mathrm{CPI}=6.66>1)$. Nilai Kontrak penyelesaian proyek keseluruhan dari data yang diterima yaitu sebesar Rp 3.445.257.000, sedangkan biaya total proyek yang didapat berdasarkan Metode Konsep Nilai Hasil adalah sebesar Rp 2.939.332.030, menunjukkan biayapelaksanaan proyek lebih kecil dari anggaran.
\end{abstract}

Kata Kunci : Konsep Nilai Hasil, Kinerja Biaya. 


\section{PENDAHULUAN}

\section{Latar Belakang Masalah}

Pembangunan di bidang jasa konstruksi sekarang ini masih terus dilakukan untuk memenuhi fasilitas-fasilitas perkantoran yang memadai.Salah satu fasilitas perkantoran yang sangat dibutuhkan sekarang ini adalah Gedung Kantor Bupati.Melihat keadaan Kabupaten Toraja Utara sekarang yang masih dalam tahap pembangunan maka sangat dibutuhkan gedung-gedung perkantoran. Dalam hal ini gedung perkantoran yang akan dibangun hanya bersifat sementara.Dalam perencanaan gedung tidak hanya menghitung kekuatan konstruksi tetapi juga menghitung biaya yang dibutuhkan dalam pelaksanaan di lapangan atau biasa disebut rencana anggaran biaya (RAB). Rencana anggaran biaya yang direncanakan pada suatu pembangunan harus efisien dan optimal. Banyak hal dilakukan sebelum membuat RAB, diantaranya pemantapan desain dan bahan yang akan dipakai. Pemilihan desain dan bahan sangat penting dilakukan karena akan menunjukkan mutu dan kualitas daripada bangunan tersebut.

Perencanaan pembangunan Kantor Sementara Bupati ini membutuhkan biaya yang cukup banyak. Gedung ini direncanakan dibangun 2 (Dua) lantai dengan ketersediaan dana yang terbatas sehingga diperlukan adanya perencanaan yang baik dan matang sebelum proyek dilaksanakan. Perhatian yang besar terutama dibutuhkan terhadap pengawasan mutu pekerjaan dan pengendalian pelaksanaan proyek dengan tujuan proyek dapat diselesaiakan sesuai rencana biaya.

Perencanaan dan pengendalian biaya merupakan bagian dari manajemen proyek konstruksi secara keseluruhan. Selain penilaian dari segi kualitas, kinerja suatu proyek dapat pula dinilai dari segi biaya. Biaya yang telah dikeluarkan digunakan dalam menyelesaikan suatu proyek harus diukur secara kontinyu penyimpangannya terhadap rencana yang telah dibuat sebelumnya. Adanya penyimpangan biaya yang signifikan mengindikasikan pengelolaan proyek kurang optimal. Dengan adanya indikator prestasi proyek dari segi biaya ini memungkinkan 
tindakan pencegahan agar pelaksanaan proyek berjalan sesuai biaya yang direncanakan.Kinerja biaya proyek Kantor Bupati tersebut yang akan kami lakukan berdasarkan Metode Analisa SNI dan Analisa Biaya Konstruksi Bangunan Gedung dan Perumahan. Perhitungan didasarkan sesuai data biaya yang dianggarkan untuk pekerjaan yang direncanakan.

\section{KAJIAN LITERATUR}

\subsection{Metode Pengendalian Proyek}

Pembahasan dalam penelitian ini dikaji secara deskriptif. Metode pengendalian proyek yang digunakan adalah Metode pengendalian Biaya Terpadu (Earned Value ). Metode ini mengkaji kecenderungan Varian Biaya pada suatu periode waktu selama proyek berlangsung ( Iman Soeharto,1997).

Metode Analisis Varians, Metode Analisis Varian adalah metode untuk mengendalikan biaya pada suatu proyek konstruksi. Dalam metode ini identifikasi dilakukan dengan membandingkan jumlah biaya yang sesungguhnya dikeluarkan terhadap anggaran. Analisis Varians dilakukan dengan megumpulkan informasi tentang status terakhir kemajuan proyek pada saat pelaporan dengan menghitung jumlah unit pekerjaan yang telah diselesaikan kemudian dibandingkan dengan perencanaan atau melihat catatan penggunaan sumber daya. Metode ini memperlihatkan perbedaan antara biaya pelaksanaan terhadap anggaran.Varians dengan Grafik "S ", Grafik atau Kurva "S " menggambarkan kemajuan kemajuan volume pekerjaan yang diselesaikan sepanjang siklus proyek. Bila grafik tersebut dibandingkan dengan grafik serupa yang disusun berdasarkan perencanaan dasar maka akan segera terlihat jika terjadi penyimpangan. Grafik "S " sangat bermanfaat untuk dipakai sebagai laporan bulanan dan laporan kepada pimpinan proyek, karena grafik ini dapat dengan jelas menunjukkan kemajuan proyek dalam bentuk yang mudah dipahami. 


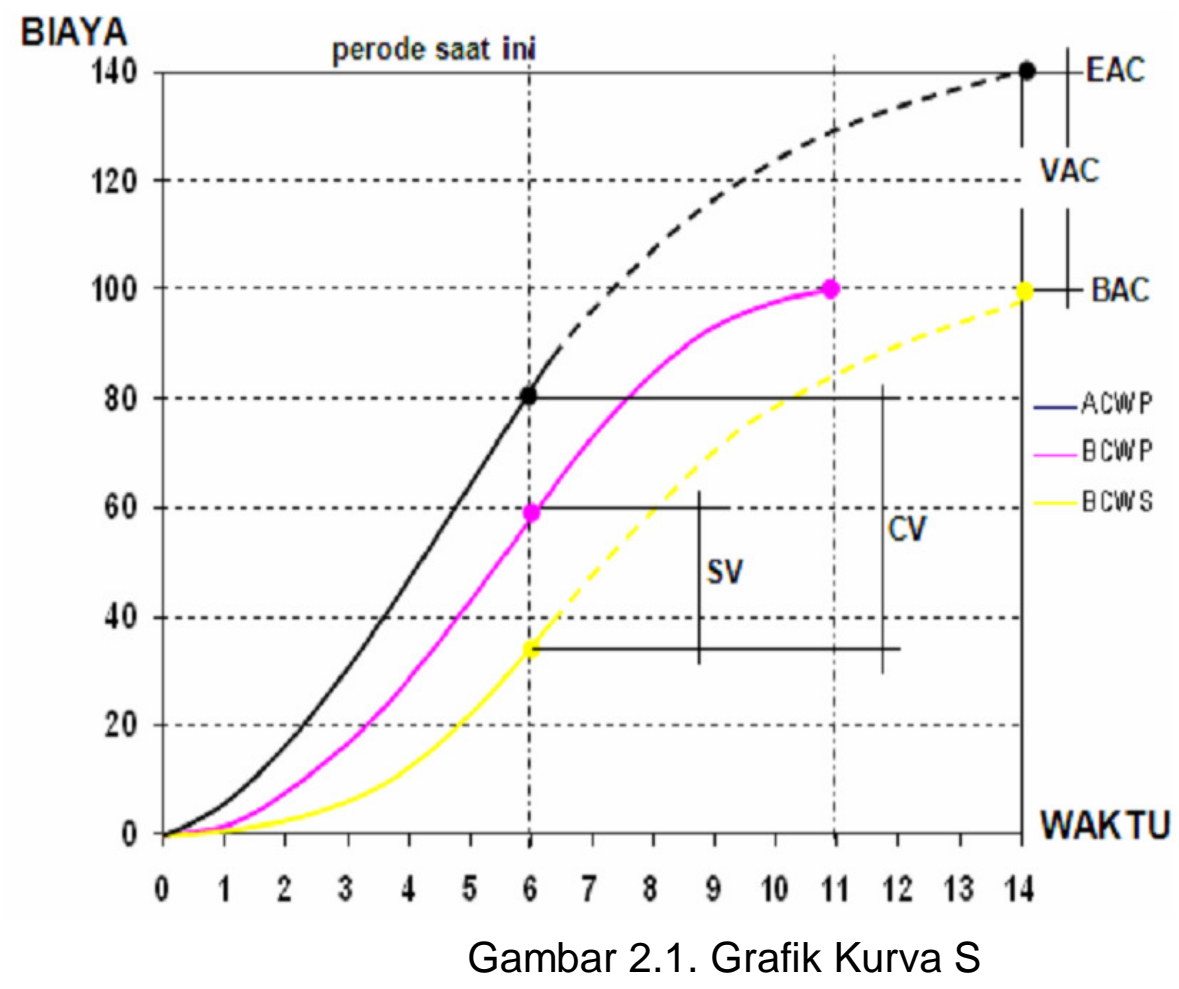

Kombinasi Bagan Balok dan Grafik kurva "S ", Salah satu teknik pengendalian kemajuan proyek adalah memakai kombinasi grafik kurva " $S$ " dan tonggak kemajuan (milestone). Milestone adalah titik yang menandai suatu peristiwa yang dianggap penting dalam rangkaian pelaksanaan pekerjaan proyek. Titik milestone ditentukan pada waktu pembuatan perencanaan dasar yang disiapkan sebagai tolak ukur kegiatan pengendalian kemajuan proyek. Penggunaan milestone yang dikombinasikan dengan Grafik kurva "S " amat efektif untuk mengendalikan pembayaran berkala.

\section{Biaya Aktual ( Actual Cost $=$ AC )}

Biaya actual ( Actual Cost $=$ AC) atau Actual Cost of Work Perfomed ( ACWP ) adalah jumlah biaya actual pekerjaan yang telah dilaksanakan pada kurun pelaporan tertentu. Biaya ini diperoleh dari data-data akuntansi atau keuangan proyek pada tanggal pelaporan. Jadi AC merupakan jumlah aktual dari pengeluaran dana yang digunakan untuk melaksanakan pekerjaan pada kurun waktu tertentu. 
Nilai Hasil ( Earned Value $=\mathrm{EV}$ )

Nilai hasil $($ Earned Value $=\mathrm{EV})$ atau Budgeted Cost of Work Performed $($ BCWP) adalah nilai pekerjaan yang telah selesai terhadap anggaran yang disediakan untuk melaksanakan pekerjaan tersebut. Bila angka AC dibandingkan dengan EV, akan terlihat perbandingan antara biaya yang telah dikeluarkan untuk pekerjaan yang telah terlaksana terhadap biaya yang seharusnya dikeluarkan untuk maksud tersebut.Secara umum dapat dirumuskan sebagai berikut :

\section{$E V=(\%$ progress actual $) \times($ anggaran $)$}

Dimana :EV : Earned Value, \% progress actual yang dicapai saat pelaporan, Anggaran yang dimaksud adalah real cost biaya proyek, Jadwal Anggaran $($ Planned Value $=$ PV $)$.

Jadwal anggaran ( Planned Value $=$ PV ) atau Budgeted Cost of Work Schedule (BCWS) menunjukkan anggaran untuk suatu paket pekerjaan, yang disusun dan dikaitkan dengan jadual pelaksanaan. Disini terjadi perpaduan antara biaya, jadwal dan lingkup kerja, dimana pada setiap elemen pekerjaan telah diberi alokasi biaya dan jadwal yang dapat menjadi tolak ukur dalam pelaksanaan pekerjaan.Secara umum dapat dirumuskan sebagai berikut:

\section{$\mathrm{PV}=(\%$ progress rencana $) \times($ anggaran $)$}

Dimana :PV : Planned Value, \% progress rencana proyek, Anggaran yang dimaksud adalah real cost biaya proyek

\section{Status Kinerja dan Indeks Produktivitas}

Pengelola proyek sering kali ingin mengetahui efisiensi penggunaan sumber daya, yang dapat dinyatakan sebagai produktivitas atau indeks kinerja.Cost Variance ( CV ) merupakan selisih antara nilai yang diperoleh setelah menyelesaikan paket - paket pekerjaan dengan biaya actual yang terjadi selama pelaksanaan proyek. CV positif menunjukkan bahwa nilai paket - paket pekerjaan yang diperoleh lebih besar dibandingkan dengan biaya yang 
dikeluarkan untuk mengerjakan paket - paket pekerjaan tersebut. Sebaliknya nilai negative menunjukkan bahwa nilai paket - paket pekerjaan yang diselesaikan lebih rendah dibandingkan dengan biaya yang sudah dikeluarkan (Iman Soeharto 2001).Secara umum dapat dirumuskan sebagai berikut :

$$
\mathrm{CV}=\mathrm{EV}-\mathrm{AC}
$$

Dimana :

CV : Cost Varian, EV : Earned Value, AC : Actual Cost

Tabel 1. Harga SV dan CV

\begin{tabular}{|c|c|c|}
\hline $\begin{array}{l}\text { Varians } \\
\text { Jadwal } \\
\text { ( SV ) }\end{array}$ & $\begin{array}{l}\text { Varians } \\
\text { Biaya } \\
(\mathrm{CV})\end{array}$ & Keterangan \\
\hline Positif & Positif & $\begin{array}{l}\text { Pekerjaan lebih cepat dari jadwal dan } \\
\text { biaya lebih kecil dari anggaran }\end{array}$ \\
\hline Nol & Positif & $\begin{array}{l}\text { Pekerjaan sesuai jadwal dan biaya lebih } \\
\text { kecil dari anggaran }\end{array}$ \\
\hline Positif & Nol & $\begin{array}{l}\text { Pekerjaan lebih cepat dan biaya sesuai } \\
\text { anggaran }\end{array}$ \\
\hline Nol & Nol & Pekerjaan sesuai jadwal dan anggaran \\
\hline Negatif & Negatif & $\begin{array}{l}\text { Pekerjaan selesai terlambat dan biaya } \\
\text { lebih tinggi dari anggaran }\end{array}$ \\
\hline Nol & Negatif & $\begin{array}{l}\text { Pekerjaan terlaksana sesuai jadwal dan } \\
\text { biaya lebih tinggi dari anggaran }\end{array}$ \\
\hline Negatif & Nol & $\begin{array}{l}\text { Pekerjaan selesai terlambat dan biaya } \\
\text { sesuai anggaran }\end{array}$ \\
\hline Positif & Negatif & $\begin{array}{l}\text { Pekerjaan selesai lebih cepat dengan } \\
\text { biaya diatas anggaran }\end{array}$ \\
\hline
\end{tabular}

Sumber :Iman Soeharto,2001 
Cost Performance Indeks(CPI ) merupakan cara untuk mengetahui efisiensi penggunaan sumber daya, atau indeks kinerja.Secara umum dapat dirumuskan sebagai berikut :

$$
\text { Indeks Kinerja Biaya }(\mathrm{CPI})=\frac{\mathrm{EV}}{\mathrm{AC}}
$$

Dimana: CPI : Cost Performance Indeks, EV : Earned Value, AC : Actual Cost.

Bila angka indeks kurang dari 1, berarti pengeluaran lebih besar daripada anggaran, Bila angka indeks lebih dari 1, berarti pengeluaran lebih kecil daripada anggaran. Semakin besar perbedaan dari angka 1, berarti penyimpangan semakin besar daripada rencana awal proyek.Perkiraan Biaya penyelesaian proyek berdasarkan indicator yang diperoleh saat pelaporan, akan memberikan petunjuk besarnya biaya pada akhir proyek (Estimation at completion = EAC ) dan perkiraan biaya untuk pekerjaan tersisa (Estimastion Temporary Cost $=$ ETC $)$.

Bila persentase pekerjaan di bawah $50 \%$ menggunakan rumus:

$$
\begin{aligned}
& \mathrm{ETC}=(\text { Anggaran }-\mathrm{EV}) \\
& \mathrm{EAC}=(\mathrm{ACWP}+\mathrm{ETC})
\end{aligned}
$$

Dimana :

$>$ ETC ( Estimate Temporary Cost $)=$ Perkiraan Biaya untuk pekerjaan tersisa.

$>$ Anggaran yang dimaksud adalah real cost biaya proyek

$>$ EV (Nilai Hasil / Earned Value )

$>$ EAC (Estimate All Cost $)=$ Perkiraan Total Biaya Proyek .

$>$ ACWP ( Actual Cost of Work Performed) / Biaya Aktual (Actual Cost $=A C)$. 


\section{METODOLOGI PENELITIAN}

Tahapan penyelengaraan proyek pembangunan secara menyeluruh dimulai dari tahap perencanaan, perancangan, pelaksanaan pembangunan fisik sampai dengan pemanfaatannya harus dikerjakan secara sistematik. Di dalam proses atau tahapan ini terdapat bermacam-macam unsur pendukung yang saling berkaitan satu sama lain. Unsur-unsur yang membentuk suatu ikatan kerja sama dimana masing-masing mempunyai peranan, fungsi dan tanggung jawab yang jelas. Tujuan yang hendak dicapai pada dasarnya adalah efisiensi yang optimum dari tenaga, waktu dan biaya proyek terhadap hasil yang diperoleh. Data-data umum dan data-data teknis sangat diperlukan demi penyelenggaraan proyek yang efektif, detail dan menyeluruh.

Berdasarkan data-data yang terkumpul maka dapat diuraikan untuk gambaran umum proyek sebagai berikut:

Nama Proyek :Pembangunan Gedung Kantor Sementara Bupati Toraja Utara Lokasi Proyek : Jl. Dr. Ratulangi, Kecamatan Rantepao, Kab. Toraja Utara Kontraktor Proyek : PT. Lintas Nusantara Permai

Konsultan Proyek : CV. Dasya Tri Karsa

Nilai Kontrak : : Rp 3.445.257.466

Sumber Dana : Dana Alokasi Umum ( DAU )

Waktu Pelaksanaan : 24 Mei 2012 sampai dengan 19 Desember 2012

Lama Pelaksanaan : 210 Hari Kalender 


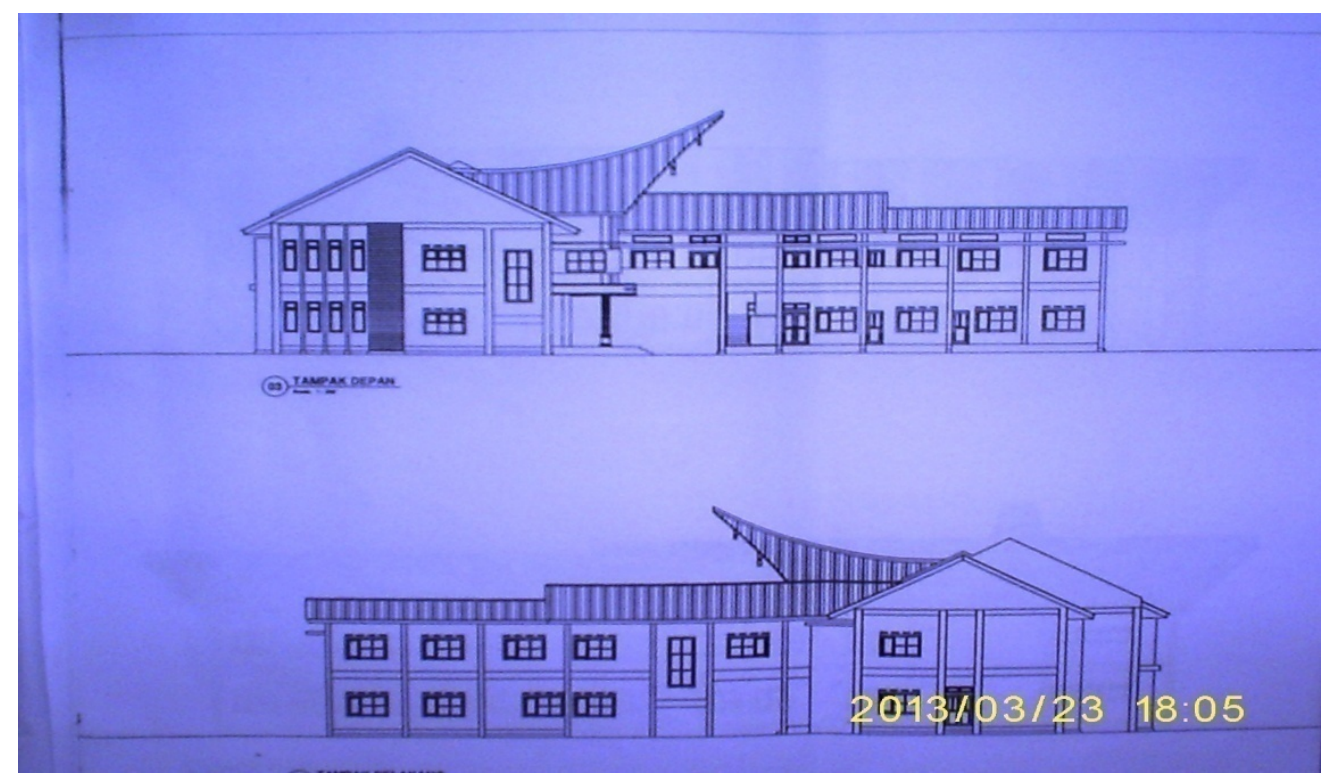

Gambar 3.1.Tampak Depan dan Tampak Belakang

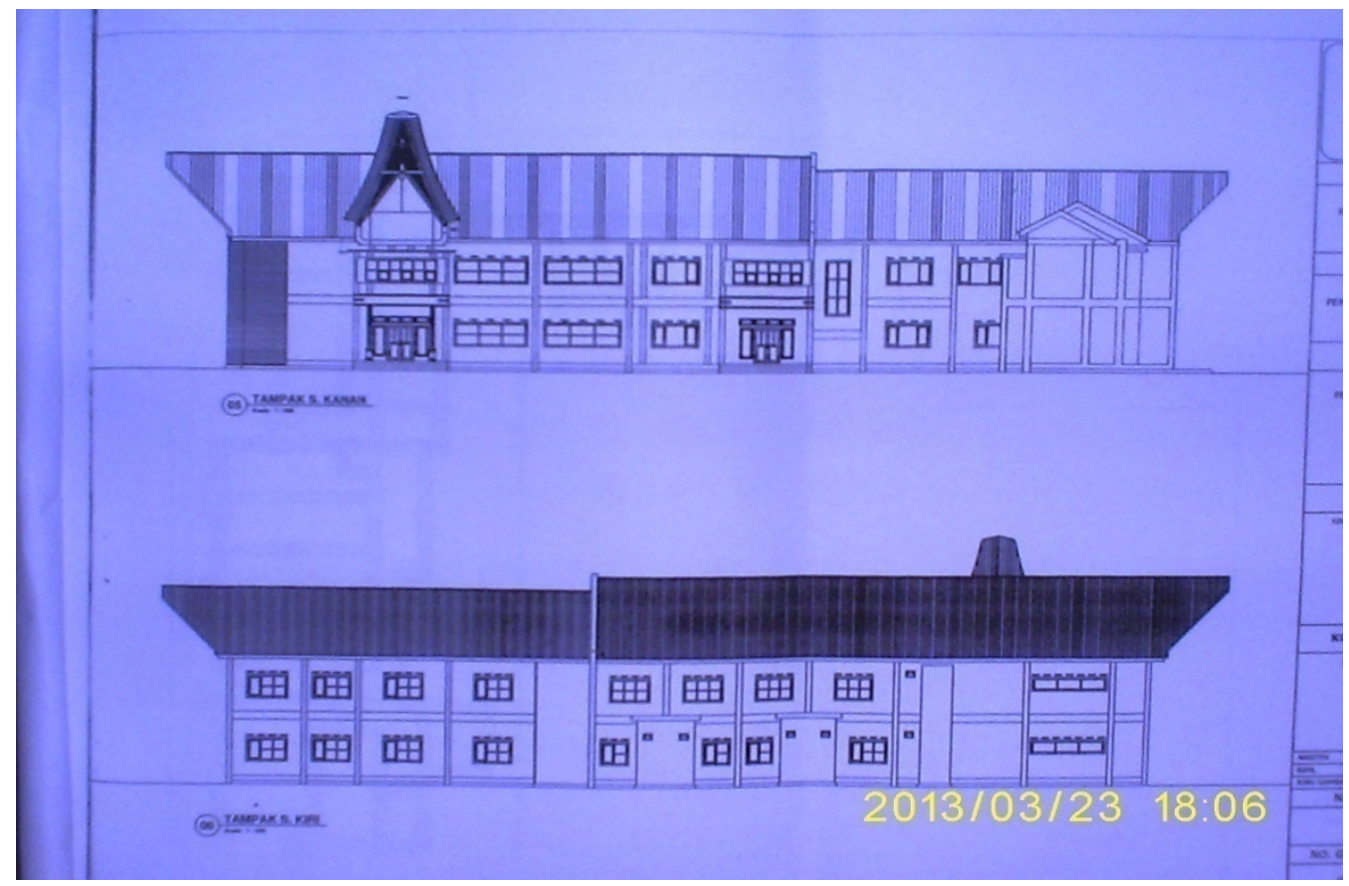

Gambar 3.2.Tampak Samping 
Pelaksanaan penelitian dalam rangka mencari jawaban atas permasalahan yang digunakan penulis yaitu : pengambilan data berupa gambar, RAB, Time Schedule, serta Laporan proyek.

\section{HASIL DAN PEMBAHASAN}

\section{Analisa Planned Value (PV) atau BCWS}

Perhitungan Planned Value pada minggu pertama sampai minggu ke enam periode $24 \mathrm{Mei}-30$ Juni 2012 dihitung dengan cara mengalikan prosentase rencana jadwal pada minggu ke - 1 sampai minggu ke -6 dengan jumlah rencana anggaran biaya pada suatu pekerjaan (Nilai Kontrak).

a. Perhitungan PV minggu ke -1 :

$\%$ komulatif minggu ke $-1=0.4 \% \rightarrow$ Lihat Tabel 4.1

Nilai kontrak $=\operatorname{Rp} 3.445 .257 .466,79$

PV minggu ke $-1=$ Prosentase komulatif rencana $\times$ nilai kontrak

$$
=0.4 \% \text { x Rp 3.445.257.466,79=Rp 13.781.029 }
$$

b. Perhitungan PV minggu ke -2 :

$\%$ komulatif minggu ke $-2=0.85 \% \rightarrow$ Lihat Tabel 4.1

Nilai kontrak $=\operatorname{Rp} 3.445 .257 .466,79$

PV minggu ke $-2=$ Prosentase komulatif rencana $\times$ Nilai kontrak

$$
=0.85 \% \times \text { Rp 3.445.257.466,79 = Rp 29.284.688 }
$$

c. Perhitungan PV minggu ke -3 :

$\%$ komulatif minggu ke $-3=1.83 \% \rightarrow$ Lihat Tabel 4.1

Nilai Kontrak $=\operatorname{Rp} 3.445 .257 .466,79$

PV minggu ke $-3=$ Prosentase komulatif rencana $\times$ Nilai kontrak

$$
=1.83 \% \times \text { Rp 3.445.257.466,79 = Rp 63.048.211 }
$$

d. Perhitungan PV minggu ke -4 :

$\%$ komulatif minggu ke $-4=2.81 \% \rightarrow$ Lihat Tabel 4.1

Nilai Kontrak $=\operatorname{Rp} 3.445 .257 .466,79$

PV minggu ke $-4=$ Prosentase komulatif rencana $\times$ Nilai kontrak

$$
=2.81 \% \times \operatorname{Rp} 3.445 .257 .466,79=\operatorname{Rp} 96.811 .734
$$

e. Perhitungan PV minggu ke-5 :

$\%$ komulaif minggu ke- $5=4.10 \% \rightarrow$ Lihat Tabel 4.1 
Nilai Kontrak = Rp 3.445.257.466,79

PV minggu ke- $5=$ Prosentase komulatif rencana $\times$ Nilai kontrak

$$
=4.10 \% \text { xp 3.445.257.466,79 = Rp 141.255.556 }
$$

f. Perhitungan PV minggu ke-6 :

$\%$ komulatif minggu ke-6 $=5.40 \% \rightarrow$ Lihat Tabel 4.1

Nilai Kontrak $=$ Rp 3.445.257.466,79

PV minggu ke- $6=$ Prosentase komulatif rencana $\times$ Nilai kontrak

$$
=5.40 \% \times \text { Rp 3.445.257.466,79 = Rp 186.043.903 }
$$

Hasil perhitungan PV atau BCWS berikutnya dapat dilihat pada table dibawah ini :

\begin{tabular}{|c|c|c|}
\hline $\begin{array}{l}\text { Minggu } \\
\mathrm{Ke}-\end{array}$ & $\begin{array}{l}\text { Komulatif Rencana } \\
\%\end{array}$ & Nilai PV atau BCWS \\
\hline 1 & $0,4 \%$ & Rp 13.781.029 \\
\hline 2 & $0.85 \%$ & $\operatorname{Rp} 29.284 .688$ \\
\hline 3 & $1.83 \%$ & Rp 63.048.211. \\
\hline 4 & $2.81 \%$ & Rp 96.811.734 \\
\hline 5 & $4.10 \%$ & Rp 141.255.556 \\
\hline 6 & $5.40 \%$ & Rp 186.043.903 \\
\hline 7 & $10.79 \%$ & Rp 371.743.280 \\
\hline 8 & $15.63 \%$ & Rp 538.493.741 \\
\hline 9 & $20.47 \%$ & Rp 705.244.203 \\
\hline 10 & $25.31 \%$ & Rp 871.994.664 \\
\hline 11 & $29.41 \%$ & Rp 1.013.250.221 \\
\hline 12 & $34.08 \%$ & Rp 1.174.143.744 \\
\hline 13 & $38.45 \%$ & Rp 1.324.701.496 \\
\hline 14 & $44.33 \%$ & $\operatorname{Rp} 1.527 .282 .635$ \\
\hline 15 & $48.17 \%$ & Rp 1.659.580.521 \\
\hline 16 & $53.47 \%$ & Rp 1.842.179.167 \\
\hline 17 & $61.62 \%$ & Rp 2.122.967.651 \\
\hline 18 & $69.32 \%$ & Rp 2.388.252.475 \\
\hline 19 & $76.03 \%$ & Rp 2.619.429.251 \\
\hline 20 & $80.80 \%$ & Rp 2.783.768.033 \\
\hline
\end{tabular}

Tabel 4.1.Analisa PV atau BCWS 


\begin{tabular}{|l|l|l|}
\hline 21 & $84.95 \%$ & Rp 2.926.746.217 \\
\hline 22 & $89.16 \%$ & Rp 3.071.791.557 \\
\hline 23 & $92.19 \%$ & Rp 3.176.182.858 \\
\hline 24 & $95.37 \%$ & Rp 3.285.742.045 \\
\hline 25 & $97.78 \%$ & Rp 3.368.772.751 \\
\hline 26 & $98.86 \%$ & $\operatorname{Rp~3.405.981.531~}$ \\
\hline 27 & $99.43 \%$ & $\operatorname{Rp~3.425.619.498~}$ \\
\hline 28 & $100.00 \%$ & Rp 3.445.257.466 \\
\hline
\end{tabular}

Sumber : Data proyek

\section{Analisa Earned Value ( EV) atau BCWP}

Perhitungan Earned Value (EV) pada periode 24 Mei - 30 Juni 2012 dapat dihitung dengan cara mengalikan prosentase realisasi jadwal pada minggu pertama sampai minggu ke enam dengan jumlah rencana anggaran biaya pada suatu pekerjaan ( Nilai Kontrak).

a. Perhitungan EV pada minggu ke - 1 :

$\%$ komulatif minggu ke-1 $=2,10 \% \rightarrow$ Lihat Tabel 4.2

Nilai Kontrak $=\operatorname{Rp} 3.445 .257 .466,79$

EV minggu ke -1 : Prosentase realisasi $\times$ Nilai kontrak

$$
: 2,10 \% \text { x Rp 3.445.257.466,79 = Rp 72.350.406,79 }
$$

b. Perhitungan EV pada minggu ke -2 :

$\%$ komulatif minggu ke- $2=6,19 \% \rightarrow$ Lihat Tabel 4.2

Nilai Kontrak $=\operatorname{Rp} 3.445 .257 .466,79$

EV minggu ke -2 : Prosentase realisasi $x$ Nilai kontrak

$$
\text { : 6,19 \% x Rp 3.445.257.466,79 = Rp 213.261.437 }
$$

c. Perhitungan EV pada minggu ke -3 :

$\%$ komulatif minggu ke $-3=9.83 \% \rightarrow$ Lihat Tabel 4.2

Nilai Kontrak $=\operatorname{Rp} 3.445 .257 .466,79$

EV minggu ke -3 : Prosentase realisasi $x$ Nilai kontrak

$$
\text { : } 9.83 \% \text { x Rp 3.445.257.466,79 = Rp 338.668.808 }
$$

d. Perhitungan EV pada minggu ke -4 :

$\%$ komulatif minggu ke $-4=13.15 \% \rightarrow$ Lihat Tabel 4.2 
Nilai Kontrak $=\operatorname{Rp} 3.445 .257 .466,79$

EV minggu ke -4 : Prosentase realisasi $x$ Nilai kontrak

$$
\text { : } 13.15 \% \text { x 3.445.257.466,79 = Rp 453.051.356 }
$$

a. Perhitungan EV pada minggu ke -5 :

$\%$ komulatif minggu ke- $5=14.65 \% \rightarrow$ Lihat Tabel 4.2

Nilai Kontrak $=\operatorname{Rp} 3.445 .257 .466,79$

EV minggu ke- 5 : Prosentase realisasi $x$ Nilai kontrak

$$
: 14.65 \% \times 3.445 .257 .466,79=\operatorname{Rp} 504.730 .218
$$

b. Perhitungan EV pada minggu ke- 6 :

$\%$ komulatif minggu ke- $6=18.23 \% \rightarrow$ Lihat table 4.2

Nilai Kontrak $=\operatorname{Rp} 3.445 .257 .466,79$

EV minggu ke- 6 : Prosentase realisasi $\times$ Nilai kontrak

$$
\text { : 18.23\% x Rp 3.445.257.466,79 = Rp 628.070.436 }
$$

Tabel 4.2. Analisa Earned Value Pada Pelaporan Pertama

\begin{tabular}{|l|l|l|}
\hline $\begin{array}{l}\text { Minggu } \\
\text { Ke }-\end{array}$ & $\begin{array}{l}\text { Komulatif Realisasi } \\
\%\end{array}$ & Nilai EV \\
\hline 1 & $2.10 \%$ & Rp 72.350 .406 \\
\hline 2 & $6.19 \%$ & Rp 213.261.437 \\
\hline 3 & $9.83 \%$ & Rp 338.668.808 \\
\hline 4 & $13.15 \%$ & Rp 453.051 .356 \\
\hline 5 & $14.65 \%$ & Rp 504.730.218 \\
\hline 6 & $18.23 \%$ & Rp 628.070.436 \\
\hline
\end{tabular}

Sumber : Data proyek

\section{Perhitungan Biaya Aktual (Actual Cost) atau ACWP}

Perhitungan Biaya Aktual pada minggu pertama sampai minggu ke enam periode $24 \mathrm{Mei}-30$ Juni didapat dari jumlah biaya yang dikeluarkan seperti tabel di bawah ini : 
Tabel 3.Analisa Aktual Cost Pada Pelaporan Pertama

\begin{tabular}{|l|l|l|}
\hline $\begin{array}{l}\text { Minggu } \\
\text { Ke- }\end{array}$ & Total AC ( Rp ) & \multicolumn{1}{|c|}{ Keterangan } \\
\hline 1 & Rp 3.016 .000 & Biaya material ( Pasir ) \\
\hline 2 & Rp 11.275 .000 & Biaya material ( Cipping ) \\
\hline 3 & Rp 7.500 .000 & Bekisting \\
\hline 4 & Rp 4.312 .000 & Material took \\
\hline 5 & Rp 1.783 .000 & ATK \\
\hline 6 & Rp 94.259 .000 & Upah kerja DLL \\
\hline
\end{tabular}

Sumber : Data proyek ( Lampiran II )

Status kinerja biaya proyek periode $24 \mathrm{Mei}-30$ Juni dapat ditunjukkan dari indicator Cost Varian ( CV), dan Indeks Kinerja Biaya ( CPI). Proyeksi pengeluaran biaya untuk pekerjaan tersisa (ETC) \& penyelesaian proyek (EAC).

\section{Cost Varian atau Varian Biaya ( CV ) dan Indeks Kinerja Biaya ( CPI)}

Cost Varience atau Varian Biaya ( CV ) merupakan selisih antara nilai yang diperoleh setelah menyelesaikan paket-paket pekerjaan dengan Biaya Aktual yang terjadi selama pelaksanaan proyek.

\section{Varian Biaya $(\mathrm{CV})=\mathrm{EV}-\mathrm{AC}$ atau CV $=\mathrm{BCWP}-\mathrm{ACWP}$}

Contoh perhitungan $\mathrm{CV}$ pada minggu pertama:

$\mathrm{CV}=\mathrm{EV}-\mathrm{AC}$

$C V=R p 72.350 .406-R p 3.016 .000=\operatorname{Rp} 69.334 .406$

Hasil perhitungan CV minggu berikutnya dapat dilihat pada table 4.4.

Indeks Kinerja Biaya atau Cost Performance Indeks ( CPI) adalah untuk mengetahui efesiensi penggunaan sumberdaya.

Indeks Kinerja Biaya $(\mathrm{CPI})=\frac{\mathrm{EV}}{\mathrm{AC}}$

Contoh perhitungan CPI pada minggu pertama: 
$\mathrm{CPI}=\frac{\mathbf{7 2 . 3 5 0 . 4 0 6}}{\mathbf{3 . 0 1 6 . 0 0 0}}, \mathrm{CPI}=23.98$

Hasil perhitungan CPI minggu berikutnya dapat dilihat dalam table 4.4.

Tabel 4.4.Status Kinerja Biaya Proyek periode 24 Mei - 30 Juni

\begin{tabular}{|l|c|c|c|c|l|}
\hline \multirow{2}{*}{$\begin{array}{l}\text { Ming } \\
\text { Ke- }\end{array}$} & PV & EV & AC & $\begin{array}{l}\text { CV= } \\
\text { EV-AC }\end{array}$ & $\begin{array}{l}\text { CPI= } \\
\text { EV / AC }\end{array}$ \\
\cline { 2 - 6 } & Rp & Rp & Rp & Rp & \\
\hline 1 & 13.781 .029 & 72.350 .406 & 3.016 .000 & 69.334 .406 & 23.98 \\
\hline 2 & 29.284 .688 & 213.261 .437 & 11.275 .000 & 202.000 .000 & 18.91 \\
\hline 3 & 63.048 .211 & 338.668 .808 & 7.500 .000 & 331.168 .808 & 44.88 \\
\hline 4 & 96.811 .734 & 453.051 .356 & 4.312 .000 & 448.739 .356 & 105.06 \\
\hline 5 & 141.255 .556 & 504.730 .218 & 1.783 .000 & 502.947 .218 & 283.07 \\
\hline 6 & 186.043 .903 & 628.070 .436 & 94.259 .000 & 533.811 .436 & 6.666 \\
\hline
\end{tabular}

Sumber: Data proyek

Status Kinerja Biaya Proyek pada saat pelaporan pada akhir bulan Juni menunjukkan Kinerja Proyek untung, hal ini ditunjukkan dari indicator Varian Biaya ( CV ) bernilai positif sebesar Rp. 533.811 .436 selisih nilai hasil ( EV) dengan biaya actual yang dikeluarkan ( $A C)$. Indikator Indeks Kinerja Biaya pada saat pelaporan juga menunjukkan $\mathrm{CPI}=6.66>1$ lebih besar dari 1 , berarti pengeluaran lebih kecil daripada anggaran.

\section{Proyeksi Pengeluaran Biaya Untuk Pekerjaan Tersisa (ETC) dan}

\section{Penyelesaian Proyek (EAC)}

Adapun besarnya biaya untuk pekerjaan tersisa ( ETC) pada Proyek

Pembangunan Gedung Kantor Bupati Sementara diekstrapolasi dengan cara :

a. Pekerjaan sisa memakan biaya sebesar anggaran, tidak tergantung dari prestasi yang telah dicapai sampai dengan saat pelaporan.

b. Kinerja sama besar sampai akhir proyek, beranggapan angka kinerja pada saat pelaporan akan tetap bertahan sampai akhir proyek.

c. Penyelesaian pekerjaan pada proyek di atas pada saat pelaporan pertama masih dibawa $50 \%$.

ETC $=($ Anggaran - EV $)$ 
Contoh perhitungan ETC :

$\mathrm{ETC}=($ Anggaran $-\mathrm{EV})$

$\mathrm{ETC}=($ Rp 3.445.257.466 $-\mathrm{Rp} 72.350 .406)=\mathrm{Rp} 3.372 .907 .060$

Hasil perhitungn ETC minggu berikutnya dapat dilihat dalam tabel 4.5.

EAC merupakan prakiraan total Biaya pada akhir Proyek, dengan

mengasumsikan bahwa kecenderungan angka kinerja biaya yang terjadi pada saat pelaporan akan tetap sampai akhir proyek. Sehingga biaya total proyek diperkirakan sebesar pengeluaran actual yang dikeluarkan sampai dengan saat pelaporan ditambahkan biaya untuk pekerjaan tersisa ( ETC ).

\section{$E A C=(A C$ atau ACWP + ETC $)$}

Contoh perhitungan EAC :

$E A C=A C W P+E T C$

$E A C=R p 3.016 .000+R p$ 3.372.907.060 $=R p$ 3.375.923.060

Hasil perhitungan EAC selanjutnya dapat dilihat dalam tabel 4.5.

Jadi, prakiraan total biaya proyek (EAC) adalah

$$
\begin{aligned}
& E A C=A C W P+E T C \\
& E A C=R p 122.145 .000+R p 2.817 .187 .030=R p 2.939 .332 .030
\end{aligned}
$$

Jumlah anggaran pada Proyek Pembangunan Gedung Kantor Sementara Bupati Toraja Utara ini adalah sebesar Nilai Kontrak Rp 3.445.257.466,79 sedangkan jumlah biaya prakiraan total proyek adalah sebesar Rp 2.939.332.030, berarti ada penyimpangan sebesar Rp 505.925.436.

Tabel 5.Proyeksi Biaya ETC dan EAC

\begin{tabular}{|l|l|l|l|l|l|l|}
\hline $\begin{array}{l}\text { Mingg } \\
\mathrm{u} \\
\text { Ke- }\end{array}$ & $\mathrm{PV}=\mathrm{BCWS}$ & $\begin{array}{l}\mathrm{EV}=\mathrm{PCW} \\
\mathrm{P}\end{array}$ & $\mathrm{AC}=\mathrm{ACWP}$ & $\mathrm{CPI}$ & $\begin{array}{l}\mathrm{ETC}= \\
\mathrm{BAC}-\mathrm{EV}\end{array}$ & $\begin{array}{l}\mathrm{EAC}= \\
\mathrm{ACWP}+\mathrm{ETC}\end{array}$ \\
\cline { 2 - 7 } & $\mathrm{Rp}$ & $\mathrm{Rp}$ & $\mathrm{Rp}$ & & $\mathrm{Rp}$ & $\mathrm{Rp}$ \\
\hline 1 & 13.781 .029 & $\begin{array}{l}72.350 .40 \\
6\end{array}$ & 3.016 .000 & 23.98 & 3.372 .907 .060 & 3.375 .923 .060 \\
\hline 2 & 29.284 .688 & $\begin{array}{l}213.261 .4 \\
37\end{array}$ & 11.275 .000 & 18.91 & 3.231 .996 .029 & 3.243 .271 .029 \\
\hline 3 & 63.048 .211 & $\begin{array}{l}338.668 .8 \\
08\end{array}$ & 7.500 .000 & 44.88 & 3.106 .588 .658 & 3.114 .088 .658 \\
& & & & & \\
\hline
\end{tabular}




\begin{tabular}{|c|c|c|c|c|c|c|}
\hline 4 & 96.811 .734 & $\begin{array}{l}453.051 .3 \\
56\end{array}$ & 4.312 .000 & 105.06 & 2.992 .206 .110 & 2.996 .518 .110 \\
\hline 5 & 141.255 .556 & $\begin{array}{l}504.730 .2 \\
18\end{array}$ & 1.783 .000 & 283.07 & 2.940 .527 .248 & 2.942 .310 .248 \\
\hline 6 & 186.043 .903 & $\begin{array}{l}628.070 .4 \\
36\end{array}$ & 94.259 .000 & 6.666 & 2.817 .187 .030 & 2.911 .446 .030 \\
\hline 7 & 371.743 .280 & & & & & \\
\hline 8 & 538.493 .741 & & & & & \\
\hline 9 & 705.244 .203 & & & & & \\
\hline 10 & 871.994 .664 & & & & & \\
\hline 11 & 1.013 .250 .221 & & & & & \\
\hline 12 & 1.174 .143 .744 & & & & & \\
\hline 13 & 1.324 .701 .496 & & & & & \\
\hline 14 & 1.527 .282 .635 & & & & & \\
\hline 15 & 1.659 .580 .521 & & & & & \\
\hline 16 & 1.842 .179 .167 & & & & & \\
\hline 17 & 2.122 .967 .651 & & & & & \\
\hline 18 & 2.388 .252 .475 & & & & & \\
\hline 19 & 2.619 .429 .251 & & & & & \\
\hline 20 & 2.783 .768 .033 & & & & & \\
\hline 21 & 2.926 .746 .217 & & & & & \\
\hline 22 & 3.071 .791 .557 & & & & & \\
\hline 23 & 3.176 .182 .858 & & & & & \\
\hline 24 & 3.285 .742 .045 & & & & & \\
\hline 25 & 3.368 .772 .751 & & & & & \\
\hline 26 & 3.405 .981 .531 & & & & & \\
\hline 27 & 3.425 .619 .498 & & & & & \\
\hline 28 & 3.445 .257 .466 & & 122.145 .000 & & 2.817 .187 .030 & 2.939 .332 .030 \\
\hline
\end{tabular}

Sumber: Data proyek 


\section{KESIMPULAN}

1. Kinerja biaya proyek pada pelaporan pertama yakni periode $24 \mathrm{Mei}-30$ Juni 2012 ditunjukkan dari indicator Cost Varian bernilai positif berarti biaya pekerjaan lebih kecil dari anggaran dan Indek Kinerja Biaya lebih besar dari $1(\mathrm{CPI}=6.66>1)$

2. Nilai Kontrak penyelesaian proyek keseluruhan dari data yang diterima yaitu sebesar Rp 3.445.257.000, sedangkan biaya total proyek yang didapat berdasarkan Metode Konsep Nilai Hasil adalah sebesar Rp 2.939.332.030,(Nilai Kontrak) berarti biayapelaksanaan proyek lebih kecil dari anggaran. 


\section{DAFTAR PUSTAKA}

> Bachtiar Ibrahim. ,...Rencana dan Estimate Real Of Cost,Padang, 1993.

> Dipohusudo I,...ManajemenProyekdanKonstruksiJilid I, Kanesius, Jakarta, 1996.

> Ervianto Wulfram I, ..Manajemen Proyek Konstruksi; - Edisi.III, Yogyakarta, 2003.

> Ervianto Wulfram , ..Eksplorasi Teknologi dalam Proyek Konstruksi; Edisi. I, Yogyakarta, 2006.

$>$ Ervianto Wulfram , ..Cara Tepat Menghitung Biaya Bangunan;-Edisi I, Yogyakarta, 2007.

> Nurhayati,..Manajemen Proyek; Edisi I., Yogyakarta, 2010.

> Mansyur,..Manajemen Pembiayaan Proyek,Yogyakarta,2012.

> Malik Alfian,...Pengantar Bisnis Jasa Pelaksana Konstruksi; - Edisi I.,Yogyakarta, 2010.

> Mahadewi, EvaluasiProyekdenganKonsepNilaiHasil ( Earned Value Concept ) padaproyekpembangunanGedungInstalasiRehabilitasiMedik RS Sanglah Denpasar, Skripsi, TeknikSipil UNUD.

> Soeharto, Imam. ManajemenProyekdariKonseptualsampaiOperasional, Erlangga, Jakarta, 1997. 